\title{
THE USE OF PANCURONIUM BROMIDE IN PATIENTS RECEIVING LITHIUM CARBONATE
}

\author{
Herman Borden, m.D., Maxine T. Clarke, m.D., and Herzl Katz, m.d.
}

\section{Pancuronium Bromide and Lithium Carbonate}

LiтHIU,, discovered in 1818 by Arfevedson, was introduced into psychiatry as a psychotherapeutic agent in 1949 for the treatment of acute manic episodes. Psychopharmacology of the agent has extended its use to prophylactic treatment. ${ }^{1,2,3}$ Now, after 20 years of experience in the treatment of acute and recurrent mania, ${ }^{4,5,6}$ it is hailed by some for use in many forms of mental illness. Psychiatric patients coming to operation may be on maintenance therapy with this intriguing agent.

Case History: A female librarian 58 years of age with the diagnosis of bronchiectasis was scheduled for elective thoracotomy, probable left lower lobectomy. She weighed $69 \mathrm{~kg}$. Laboratory values were: haemoglobin 11.5 grams per cent, haematocrit $34 \mathrm{~mm}$, RBC $3.8 \mathrm{M} / \mathrm{cmm}$, MCV 90 . MCH 29, MCHC 33, WBC 5,800. Differential: Segs 53 per cent, lymphs 38 per cent, monos 2 per cent, eosinophiles 7 per cent. Total protein 5.7, albumin 3.4, calcium 9.3, phos 3.2 , cholesterol 213, uric acid 5.5, creatinine 1.0. T. Bil 0.3, alkaline phosphatase 43, LDH 162, SGOT 17.

Pulmonary function studies pre-operatively gave the following information:

$\begin{array}{lrrr}\text { VC } & 2320 & 76 \% & \text { predicted } \\ \text { TLC } & 3960 & 80 \% & " \\ \text { IC } & 1840 & 90 \% & \prime \\ \text { ERV } & 480 & 47 \% & \prime \\ \text { FRC } & 2120 & 74 \% & \prime \\ \text { RV } & 1640 & 88 \% & \\ \text { EV }(1 \mathrm{sec}) & 2120 & & \\ \text { Timed VC }(1 \mathrm{sec}) & 82 \% \\ \text { Max. Insp. flow rate }(1 / \mathrm{min}) 200 \\ \text { Max. Exp. flow rate }(1 / \mathrm{min}) 250 \\ \mathrm{~N}_{2} \text { elimination } 0.6 \% \\ \text { PaCO }_{2} \text { 37 Torr. }\end{array}$

Intra-operative blood gas analyses were within normal limits.

Anaesthesia was maintained with $70 \%-30 \%$ nitrous oxide and oxygen, with supplemental intravenous narcotic (fentanyl). Temperature ranged between $37.6^{\circ} \mathrm{C}$ and $37^{\circ} \mathrm{C}$.

Saint John's Hospital, 1328 22nd Street, Santa Monica, California 90404.

Canad. Anaesth. Soc. J., vol. 21, no. 1, January 1974 
The patient had received lithium carbonate $300 \mathrm{mg}$ q.i.d. for three days prior to operation. Serum lithium level the day prior to the operation was $0.8 \mathrm{mEq} / 1$ and $0.9 \mathrm{mEq} / 1$ the morning of operation.

Following $300 \mathrm{mg}$ sodium thiamylal, $80 \mathrm{mg}$ succinylcholine was given to facilitate orotracheal intubation. A Burroughs-Wellcome block-aid monitor and a manometer with control syringe were used to measure the adductor pollicis twitch response. After 80 per cent recovery, $4 \mathrm{mg}$ pancuronium bromide (0.06 $\mathrm{mg} / \mathrm{kg}$ ) was administered.

One hour and fifty minutes later, the twitch response showed only 50 per cent recovery and three hours following pancuronium, the recovery was only 80 per cent. Post-tetanic facilitation was not noted. Atropine $1 \mathrm{mg}$ and neostigmine methyl-sulfate $2 \mathrm{mg}$ resulted in complete recovery of twitch response.

Lithium therapy was resumed on the first post-operative day. A blood level of $1.1 \mathrm{mEq} / 1$ was present on the second post-operative day.

\section{Discussion}

When pancuronium is used in concentrations of $0.04 \mathrm{mg} / \mathrm{kg}$ to $0.08 \mathrm{mg} / \mathrm{kg}$, 90 per cent of control twitch height usually returns in less than 60 minutes after injection. Residual effects persisting after 60 minutes require explanation.

To test the presynaptic action of pancuronium, S.P. Gergis bioassayed acetylcholine release on guinea pig ileum using a frog sciatic nerve-gastrocnemius preparation. ${ }^{8}$ Pancuronium in low concentrations $(0.003-0.1 \mathrm{mcg} / \mathrm{cc})$ produced a dose-related increase in acetylcholine release from the non-stimulated muscle preparation, but at concentrations sufficient for neuromuscular blockade (1-5 $\mathrm{mcg} / \mathrm{cc}$ ), a concomitant reduction in the release of acetylcholine was noted along with a reduction of twitch height. The drug-induced $\mathrm{ACH}$ release appeared to be influenced by the entry of calcium into the nerve terminal. The exact mechanism remains to be demonstrated.

In the cat soleus nerve muscle preparation, Sohn and Aldrete found that pancuronium $(1.25-10 \mathrm{mcg} / \mathrm{kg})$ produced a dose-related depression of post-tetanic potentiation of muscle contractile strength, a phenomenon known to be of prejunctional origin. ${ }^{9}$

It is conceivable that the effect of pancuronium in decreasing pre-synaptic $\mathrm{ACH}$ release is greater than that of d-tubocurare, thus explaining the slow recovery of neuromuscular transmission after pancuronium. Foldes in studying the effects of pancuronium in man noted that in the presence of partial pancuronium block, tetanus was well sustained, ${ }^{10}$ in contradistinction to the accepted view that tetanus is poorly maintained during partial non-depolarization block.

How does lithium affect neuromuscular transmission? Vizi, Illis, Ronai and Knoll noted the reduction of $\mathrm{ACH}$ output from the terminals of guinea pig ileum longitudinal muscle strip preparations after stimulation. Their evidence indicated that lithium, accumulating inside the nerve terminals, inhibited the rate of $\mathrm{ACH}$ synthesis. This reduction of freshly synthesized $\mathrm{ACH}$ led to a reduction of $\mathrm{ACH}$ output on stimulation. ${ }^{11}$ 
If the effect of lithium in reducing $\mathrm{ACH}$ synthesis is super-imposed on that of pancuronium, which also decreases presynaptic $\mathrm{ACH}$ release, then a possible explanation for prolonged neuromuscular blockade under these circumstances becomes apparent.

The action of lithium on norepinephrine release and metabolism has also been studied.11 Lithium may increase the intraneural inactivation of norepinephrine, so reducing the amount available at the nerve terminals. Anaesthetic management here would involve the same considerations as in patients receiving rauwolfia therapy, since lithium treatment has been shown to produce a significant diminution in the stimulus-augmented release of both norepinephrine and serotonin.

The use of lithium for managing acute manic attacks and as prophylactic treatment for cyclic manias is currently accepted. Lithium as the carbonate is largely absorbed within minutes following an oral dose and absorption is virtually complete within 6-8 hours. ${ }^{12}$ Peak concentrations in serum occur within 2 to 4 hours. The half-life in serum is about 24 hours in the adult. To prevent toxicity, concentrations in plasma must be maintained within a critical and narrow range of $0.8 \mathrm{mEq} / 1$ to $1.6 \mathrm{mEq} / 1$, as in the case presented. ${ }^{13}$ Daily blood determinations are essential during therapy.

The lithium is initially distributed in total body water, but shifts intracellularly against a concentration gradient. Various tissues concentrate the drug to different degrees but there is no evidence of protein binding. ${ }^{14}$ The cerebrospinal fluid lithium level is about 40 per cent of that in serum when a steady state is reached. Lithium appears in the urine within 15 minutes following administration. Peak excretion occurs in 1 to 2 hours, followed by a slow decline over the next 6 to 7 hours. Eventually, about 95 per cent can be accounted for by urinary excretion. Ordinarily the rate of excretion is independent of urine flow and dietary sodium. Lithium as a cation will displace both sodium and potassium causing marked losses of these ions from the body. With marked sodium deficiency much greater amounts of lithium may be retained, thus explaining the poisonings that have occurred when lithium chloride was employed as a salt substitute in depleted patients being treated for congestive heart failure.

Toxic symptoms occur with concentrations from $1.6 \mathrm{mEq} / 1$ to $2 \mathrm{mEq} / 1$. Nausea, vomiting, diarrhoea, abdominal pain, thirst, dazed feelings, muscle weakness and hand tremors. In concentrations greater than $2 \mathrm{mEq} / 1$, symptoms include drowsiness, coarse tremor, muscle twitching, slowed speech, vomiting and diarrhoea. ${ }^{15}$ Since the lithium ion is more stable in the body than sodium or potassium, it is not easily removed by water diuresis, diuretics or potassium chloride. ${ }^{16}$

Altered $\mathrm{pH}$ does have an effect on the duration of neuromuscular block, but intra-operative acidaemia or alkalaemia were not present in this patient.

Walts, Lebowitz and Dillon studied the effect of ventilation and $\mathrm{pH}$ on the dose - duration curves of curare and gallamine:17,18 acidaemia reduces and alkalaemia increases the rate of recovery after curare, in contrast to gallamine. The effect of acidaemia on the neuromuscular blocking action of pancuronium is prolongation of the duration and rate of recovery, ${ }^{19}$ and similar to the effect on curare. 


\section{SUMMARY}

A surgical patient receiving lithium carbonate therapy is presented, in whom the use of the non-depolarizing muscle relaxant pancuronium bromide produced prolonged neuromuscular blockade. Possible mechanism of action involves impaired ACH synthesis and release. The physiology and pharmacology of lithium bromide are discussed.

\section{RÉSUMÉ}

Nous présentons un cas de chirurgie où le malade recevait du carbonate de lithium, chez qui le bromure de pancuronium, un myorésolutif non dépolarisant, a produit un blocage neuromusculaire prolongé. Le mécanisme d'action possible implique la synthèse et la libération de l'acétylcholine. Nous discutons la physiologie et la pharmacologie du bromure de lithium.

\section{BIBLIOGRAPHY}

1. BAAstrup, P.C. \& Scron, M. Lithium as a prophylactic agent. Its effect against recurrent depressions and manic-depressive psychosis. Arch. Gen. Psychiat. (Chicago). 16: 162172 (1967).

2. Ancst, J., Ditrrich, A., \& Goof, P. Course of endogenous affective psychosis and its modification by prophylactic administration of imipramine and lithium. Int. Pharmacophychiat. 2: 1-11 (1969).

3. Schose, M. Lithium in psychiatric therapy and phophylaxis. J. Psychiat. Res. 6: 67-95 (1968).

4. Gershon, S. Lithium in mania. Clin. Pharmacol. Ther. 11: 168-187 (1970).

5. MAGgs, R. Treatment of manic illnesses with Lithium carbonate. Brit. J. Psychiat. 109: 56-65 (1963).

6. Noyes, R., JR. Lithium carbonate: a review. Dis. Neur. Syst. 30: 318-21 (1969).

7. Gershon, S. Lithium in mania. Clinical Pharm. and Ther. 11: 168-185 (1970).

8. Gergis, S.D. Effect of pancuronium bromide on acethycholine release. Proc. Soc. Exp. Biol. Med. 139: 74-76 (1972).

9. SoHN, Y.J. \& Aldnete, J.A. Prejunctional effects of pancuronium bromide at the cat soleus neuromuscular junction. Fed. Proc. Fed. Amer. Soc. Exp. Biol. 30: 557 (1971).

10. Foldes, F.F., Klonymus, D.H., Maisel, W., Sctammas, F., \& Pan, T. Studies of pancuronium in conscious and anesthetized man. Anesthesiology 35: 496-503 (1971).

11. Vizi, E.S. Illes, P., Ronal, A., \& KNol, J. The effect of lithium on acetylcholine release and synthesis. Neuropharm. 11:521-530 (1972).

12. Paton, W.D.M., VIzi, E.S., \& FAR, O. The mechanism of acetylcholine release from parasympathetic nerves. J. Physiol. Lon. 215: 819-848 (1971).

13. Katz, R., Chase, N., \& Kapin, I.J. Evoked release of norepinephrine and serotonine from brain slices: inhibition by lithium. Science, N.Y. 162: 466-467 (1968).

14. Platman, S., Rohrlich, J., \& Fieve, R. Absorption and excretion of lithium in manicdepressive disease. Dis. Nerv. Syst. 29: 733-38 (1968).

15. Allcen, L.G. Laboratory experience of lithium toxicity in man. Acta psychiat. Scand. 207: 9-104 (1969).

16. Platman, S.R. \& FiEve, R.R. Lithium retention and excretion. The effect of sodium and fluid intake. Arch. Gen. Psychiat. (Chicago) 20: 285-289 (1969).

17. Walts, L.F. \& Dnlon, J.B. Deviations of action of d'tubocurarine and gallamine. Anesthesiology 29: 499-504 (1968).

18. Walts, L.F., Lebowrtz, M., \& Dillon, J.B. The effect of ventilation on the action of tubocurarine and gallamine. Brit. J. Anesth. 39: 845-849 (1967).

19. Norman, J., KATZ, R.L., \& SEed, R.F. Neuromuscular blocking action of pancuronium in man. 42: 702-709 (1970). 